in vivo $32: 487-491(2018)$

doi:10.21873/invivo.11265

\title{
The Association of Matrix Metalloproteinase-1 Promoter Polymorphisms with Breast Cancer
}

\author{
CHIEH-LUN HSIAO ${ }^{1,2,3^{*}}$, LIANG-CHIH LIU ${ }^{4 *}$, TZU-CHING SHIH ${ }^{5 *}$, YI-LIANG LAI ${ }^{6}$, SHIH-WEI HSU ${ }^{3,6}$, \\ HWEI-CHUNG WANG ${ }^{1,4}$, SU-YI PAN ${ }^{1,5}$, TE-CHUN SHEN ${ }^{1,3}$, CHIA-WEN TSAI $^{1}$, WEN-SHIN CHANG ${ }^{1}$, \\ CHEN-HSIEN SU ${ }^{1}$, TZONG-DER WAY ${ }^{2}$, JING-GUNG CHUNG ${ }^{2}$ and DA-TIAN BAU ${ }^{1,2,3,7}$ \\ ${ }^{1}$ Terry Fox Cancer Research Laboratory, Translational Medical Research Center, \\ ${ }^{4}$ Department of Breast Surgery, China Medical University Hospital, Taichung, Taiwan, R.O.C.; \\ ${ }^{2}$ Ph.D. Program for Biotechnology Industry, ${ }^{3}$ Graduate Institute of Biomedical Sciences, and \\ ${ }^{5}$ Department of Biomedical Imaging and Radiological Science, China Medical University, Taichung, Taiwan, R.O.C.; \\ ${ }^{6}$ Taichung Armed Forces General Hospital, Taichung, Taiwan, R.O.C.; \\ ${ }^{7}$ Department of Bioinformatics and Medical Engineering, Asia University, Taichung, Taiwan, R.O.C.
}

\begin{abstract}
Background/Aim: The family of matrix metalloproteinases (MMPs) are responsible for the homeostasis of extracellular matrix components and their genetic polymorphisms may be associated with cancer susceptibility. The serum levels of MMP-1 have been reported to be lower in breast cancer patients than healthy subjects. In the current study, we aimed at investigating the contribution of a polymorphism in the promoter region of MMP-1 to breast cancer in Taiwan. Materials and Methods: The MMP-1 rs1799705 polymorphic genotypes were genotyped among 1,232 breast cancer patients and 1,232 healthy controls by the typical polymerase chain reactionrestriction fragment length polymorphism methodology. Results: The percentages of $2 G / 2 G, 1 G / 2 G$, and $1 G / 1 G$ for MMP1 -1607 genotypes were 35.4, 40.6 and $24.0 \%$ in the breast cancer group and $34.1,43.6$, and $22.3 \%$ in the healthy control group ( $p$ trend $=0.3025$ ), respectively. The odds ratios (ORs) after adjusting for age, smoking and alcohol drinking status for those carrying $1 G / 2 G$ and $1 G / 1 G$ genotypes at MMP1 -1607 were $0.93(95 \% C I=0.76-1.11, p=0.2390)$ and 1.01 (95\%CI=0.77-1.23, $p=0.7377)$, respectively, compared
\end{abstract}

This article is freely accessible online.

*These Authors contributed equally to this study.

Correspondence to: Da-Tian Bau, Terry Fox Cancer Research Laboratory, Translational Medical Research Center, China Medical University Hospital, 2 Yuh-Der Road, Taichung, 404 Taiwan, R.O.C. Tel: +886 422053366 Ext. 5805, e-mail: datian@mail.cmuh.org.tw; artbau2@gmail.com

Key Words: Breast cancer, genotype, $M M P-1$, polymorphism, Taiwan. to those carrying the wild-type $2 G / 2 G$ genotype. Supporting this finding, the adjusted $O R$ for those carrying the $1 G$ allele at MMP-1 -1607 was 1.03 (95\%CI=0.91-1.18, $p=0.8860)$, compared to those carrying the wild-type $2 G$ allele. Our findings suggest that the polymorphic genotypes at MMPI promoter -1607 investigated in the current study, may not play a major role in determining cancer susceptibility to breast cancer in Taiwan. Other early diagnostic and predictive markers are urgently needed for personalized and precise breast cancer detection and therapy.

For many years, breast cancer has been the most common malignancy and the leading cause of female cancer mortality all over the world (1). According to the most updated report about burden of disease trends, cancers overall have increased by $34 \%$ during 199-2015 while breast cancer related deaths globally have increased to $45 \%$, a much higher level than average overall cancers (1). In Taiwan, breast cancer has the highest incidence and is ranked as the fourth leading cause of mortality among Taiwanese women (2). From the viewpoint of epidemiology, the risk factors of breast cancer in Taiwan included high caloric intake, highfat diets, early menarche, late menopause, obesity, high levels of stress, and exposure to environmental pollutants (3). Since, the prevalence and mortality rates are both very high in Taiwan and the world, to figure out feasible molecular markers for early detection and prognosis prediction of breast cancer, especially the subtype of triple negative breast cancer (TNBC), are in urgent need.

The matrix metalloproteinases (MMPs), which are also called matrixins, are a group of enzymes involved in tumor progression such as proliferation, invasion and metastasis (4, 5 ). In the literature, there are a few papers indicating that some MMP polymorphic genotypes, especially those 
in vivo $32: 487-491(2018)$

Table I. Demographics and lifestyles of the 1,232 breast cancer patients and the 1,232 healthy control women in Taiwan population.

\begin{tabular}{|c|c|c|c|c|c|c|c|}
\hline \multirow[t]{2}{*}{ Characteristic } & \multicolumn{3}{|c|}{ Controls $(\mathrm{n}=1,232)$} & \multicolumn{3}{|c|}{ Patients $(\mathrm{n}=1,232)$} & \multirow[t]{2}{*}{$p$-Value } \\
\hline & $\mathrm{n}$ & $\%$ & Mean (SD) & $\mathrm{n}$ & $\%$ & Mean (SD) & \\
\hline \multicolumn{8}{|l|}{ Age (years) } \\
\hline$<40$ & 359 & $29.1 \%$ & & 362 & $29.4 \%$ & & $0.89^{a}$ \\
\hline $40-55$ & 558 & $45.3 \%$ & & 547 & $44.4 \%$ & & \\
\hline$>55$ & 315 & $25.6 \%$ & & 323 & $26.2 \%$ & & \\
\hline Age at menarche (years) & & & $12.4(0.7)$ & & & $12.1(0.6)$ & $0.79^{\mathrm{b}}$ \\
\hline Age at birth of first child (years) & & & $29.4(1.2)$ & & & $29.8(1.4)$ & $0.63^{b}$ \\
\hline Age at menopause (years) & & & $48.8(1.8)$ & & & $49.3(2.0)$ & $0.59^{\mathrm{b}}$ \\
\hline \multicolumn{8}{|l|}{ Tumor site } \\
\hline Unilateral & & & & 1198 & $97.2 \%$ & & \\
\hline Bilateral & & & & 34 & $2.8 \%$ & & \\
\hline \multicolumn{8}{|l|}{ Family history } \\
\hline First degree (Mother, sister, and daughter) & & & & 55 & $4.5 \%$ & & \\
\hline Second degree & & & & 6 & $0.5 \%$ & & \\
\hline No history & & & & 1171 & $95 \%$ & & \\
\hline \multicolumn{8}{|l|}{ Habit } \\
\hline Cigarette smoker & 86 & $7.0 \%$ & & 170 & $13.8 \%$ & & $<0.0001^{* a}$ \\
\hline Alcohol drinker & 91 & $7.4 \%$ & & 162 & $13.1 \%$ & & $<0.0001 * \mathrm{a}$ \\
\hline
\end{tabular}

${ }^{a}$ Chi-square or ${ }^{b}$ unpaired Student's $t$-test; *Statistically significant.

implicated in the regulation of gene expression, may account for inter-individual differences of susceptibility to several types of cancer (6-14), while some others do not (15-19).

In literature, the commonly investigated MMP-1 rs1799750 promoter genotypes were reported to be non-significantly associated with breast cancer in the population of Poland (20). In particular, they found significantly higher levels of MMP-1 expression in tumor and normal breast tissue samples for $M M P-1$ rs $17997502 \mathrm{G} / 2 \mathrm{G}$ genotype than for $1 \mathrm{G} / 1 \mathrm{G}$ and $1 \mathrm{G} / 2 \mathrm{G}$ genotypes (20). Furthermore, there was a positive correlation of $M M P-1$ rs 1799750 2G/2G genotype with metastasis in axillary lymph node (20). However, the contribution of $M M P-1$ genotypes to breast cancer still needs to be validated in other populations, especially those in the East. Thus, the current study aimed at examining the genetic frequencies of $M M P-1$ rs1799750 promoter genotypes and evaluating the contribution of $M M P-1$ genotypes to the susceptibility of breast cancer in Taiwan.

\section{Materials and Methods}

Investigated breast cancer and healthy control subjects. Our study was evaluated and approved by the Institutional Review Board of China Medical University Hospital (DMR99-IRB-108). In this study, 1,232 female patients diagnosed with breast cancer were enrolled at the China Medical University Hospital and an equal number of healthy controls were matched with age and gender. Exclusion criteria for the healthy controls included metastatic cancer of another known or unknown origin, previous malignancy, and any hereditary or genetic disease. All the participants were oriented to complete a self-administered questionnaire and gave peripheral blood samples. The content of the questionnaire included questions on medical history and personal habits such as alcohol consumption and cigarette smoking. These factors were well recorded and are selectively summarized in Table I. All the enrolled individuals in this study have provided their informed consent to the tissue bank of China Medical University Hospital.

MMP-1 genotyping methodology. The genomic DNA of the peripheral blood leukocytes of each participant was extracted, aliquoted and stored as previously described $(15,21,22)$. The sequences of primer pairs for MMP-1 rs 1799750 polymorphism were designed by our team as previously published (17). Briefly, genotyping polymerase chain reaction (PCR) cycling conditions via My Cycler (Biorad, Hercules, CA, USA) for $M M P-1$ were: one cycle at $94^{\circ} \mathrm{C}$ for $5 \mathrm{~min} ; 35$ cycles of $94^{\circ} \mathrm{C}$ for $30 \mathrm{sec}, 57^{\circ} \mathrm{C}$ for $30 \mathrm{sec}$ and $72^{\circ} \mathrm{C}$ for $30 \mathrm{sec}$ and a final extension at $72^{\circ} \mathrm{C}$ for $10 \mathrm{~min}(19)$.

Statistical methodology. To ensure that the controls used were representative of the general population and to exclude the possibility of genotyping error, the deviation of the genotypic frequencies of $M M P-1$ polymorphisms in the healthy controls from those expected under the Hardy-Weinberg equilibrium was assessed using the goodness-of-fit test. Pearson's chi-square test was used to compare the distribution of the $M M P-1$ genotypes between case and control groups. The associations between the $M M P-1$ polymorphisms and breast cancer risk were estimated by computing odds ratios (ORs) and their 95\% confidence intervals (CIs) from unconditional logistic regression analysis with the adjustment for possible confounders when indicated.

\section{Results}

Comparison of demographics and lifestyles between breast cancer cases and control groups. The distributions of 
Table II. Distributions of matrix metalloproteinase-1 (MMP1) -1607 genotypic frequencies among 1,232 breast cancer cases and 1,232 healthy controls in Taiwan.

\begin{tabular}{lccll}
\hline & $\begin{array}{c}\text { Cases } \\
(\%)\end{array}$ & $\begin{array}{c}\text { Controls } \\
(\%)\end{array}$ & $\begin{array}{c}\text { Adjusted OR } \\
(95 \% \mathrm{CI})^{\mathrm{a}}\end{array}$ & $p$-Value \\
\hline MMP1 -1607 & & & & \\
$2 \mathrm{G} / 2 \mathrm{G}$ (wild-type) & $436(35.4)$ & $420(34.1)$ & 1.00 (reference) & \\
$1 \mathrm{G} / 2 \mathrm{G}$ & $500(40.6)$ & $537(43.6)$ & $0.93(0.76-1.11)$ & 0.2390 \\
$1 \mathrm{G} / 1 \mathrm{G}$ & $296(24.0)$ & $275(22.3)$ & $1.01(0.77-1.23)$ & 0.7377 \\
$\mathrm{p}$ for trend & & & & 0.3025 \\
Carrier comparison & & & & \\
$2 \mathrm{G} / 2 \mathrm{G}+1 \mathrm{G} / 2 \mathrm{G}$ & $936(76.0)$ & $957(77.7)$ & 1.00 (reference) & \\
$1 \mathrm{G} / 1 \mathrm{G}$ & $296(24.0)$ & $275(22.3)$ & 1.05 (0.78-1.51) & 0.3160 \\
$2 \mathrm{G} / 2 \mathrm{G}$ & $436(35.4)$ & $420(34.1)$ & 1.00 (reference) & \\
$1 \mathrm{G} / 1 \mathrm{G}+1 \mathrm{G} / 2 \mathrm{G}$ & $796(64.6)$ & $812(65.9)$ & $1.01(0.88-1.46)$ & 0.4984 \\
\hline
\end{tabular}

OR: Odds ratio; CI: confidence interval. aData has been adjusted with confounding factors include age, smoking and alcohol drinking status. bBased on Chi-square test without Yates' correction test.

frequencies of the basic characteristics and lifestyles of the breast cancer patients and healthy controls are summarized in Table I. Statistically, there was no difference between the two groups as for age, age at menarche, age at birth of first child, or age at menopause $(p>0.05)$. Regarding the personal habits, it was found that more breast cancer patients $(13.8$ and $13.1 \%)$ than healthy controls $(7.0$ and $7.4 \%)$ were of smoking and alcohol drinking habits $(p<0.05)$ during their life time (Table I).

Association of MMP-1 promoter genotypes and breast cancer risk. The distributions of genetic frequencies for the investigated MMP-1 -1607 polymorphism among the breast cancer patients and healthy controls are presented and compared in Table II. Compared to the wild-type genotype $(2 \mathrm{G} / 2 \mathrm{G})$ sub-group, there was no significant increased or decreased risk for the $1 \mathrm{G} / 2 \mathrm{G}$ or $1 \mathrm{G} / 1 \mathrm{G}$ genotypes, even after adjustment for the confounding factors including age, smoking and alcohol drinking status (adjusted $\mathrm{OR}=0.93$ and $1.01,95 \% \mathrm{CI}=0.76-1.11$ and $0.77-1.23$, $p=0.2390$ and 0.7377 ; respectively). In addition to the normal model, we also performed the carrier comparison in the recessive $(2 \mathrm{G} / 2 \mathrm{G}+1 \mathrm{G} / 2 \mathrm{G}$ versus $1 \mathrm{G} / 1 \mathrm{G})$ and dominant $(2 \mathrm{G} / 2 \mathrm{G}$ versus $1 \mathrm{G} / 1 \mathrm{G}+1 \mathrm{G} / 2 \mathrm{G})$ models. The results showed that either in recessive or dominant models, the $1 \mathrm{G}$-containing genotypes can significantly increase the risk of breast cancer among Taiwanese. In summary, the $1 \mathrm{G}$ allele at $M M P-1-1607$ was not a determinant of increased breast cancer risk in Taiwan (Table II).

Association of MMP-1 allelic subtypes and breast cancer risk. The frequencies of the $M M P-1$ promoter -1607 alleles among breast cancer patients and healthy control subjects are presented in Table III. Supporting the findings shown in
Table III. Allele frequencies of matrix metalloproteinase-1 (MMP1) $16071 G / 2 G$ among 1,232 breast cancer cases and 1,232 healthy controls in Taiwan.

\begin{tabular}{lcccc}
\hline Allele & $\begin{array}{c}\text { Cases (\%) } \\
\mathrm{n}=2464\end{array}$ & $\begin{array}{c}\text { Controls (\%) } \\
\mathrm{n}=2464\end{array}$ & $\begin{array}{c}\text { Adjusted OR } \\
(95 \% \mathrm{CI})^{\mathrm{a}}\end{array}$ & $p$-Value \\
\hline $\begin{array}{l}\text { MMP1 -1607 } \\
\text { Allele 2G }\end{array}$ & $1372(55.7)$ & $1377(55.9)$ & 1.00 (reference) & 0.8860 \\
Allele 1G & $1092(44.3)$ & $1087(44.1)$ & $1.03(0.91-1.18)$ & \\
\hline
\end{tabular}

OR: Odds ratio; CI: confidence interval. aData has been adjusted with confounding factors include age, smoking and alcohol drinking status. bBased on Chi-square test without Yates' correction test.

Table II, the variant $1 \mathrm{G}$ allele at $M M P-1-1607$ was not significantly associated with breast cancer risk (adjusted $\mathrm{OR}=1.03,95 \% \mathrm{CI}=0.91-1.18, p=0.8860$ ) (Table III).

Overall, the findings in Tables II and III consistently support each other.

\section{Discussion}

The extracellular matrix is dynamically regulated and plays a critical role in carcinogenesis, while MMPs and their inhibitors are responsible for maintaining the homeostasis of the components of the extracellular matrix $(23,24)$. MMPs were frequently shown to be upregulated in several types of cancer, and their expression was often associated with poor patient prognosis (25-29). The difference in the expression of MMPs in breast cancer cell lines of different tumorigenicity correlates with the biological behavior of these cells: more malignant cells expressed more MMPs than the less malignant ones (30-32).

The promoter polymorphic site of $M M P-1,-1607$, may determine the levels of MMP-1 and influence the personal susceptibility to breast cancer. In the current study, we demonstrated that the genotypes of MMP-1 -1607 were nonsignificantly associated with breast cancer in the investigated population in Taiwan (Tables II and III). This finding is similar to those results of Przybylowska, Biondi and Ghilardi, investigating breast cancer subjects in Poland (20) and Italy $(33,34)$. The contribution of $M M P-1$ polymorphic genotypes to breast cancer require further validation in multicenter and multi-population studies.

In 2012, the knockdown of $M M P-1$ was found to decrease the growth, invasive and brain metastatic capacities of breast cancer cells (35). Investigating the phenotypic differences in animals according to their genotypes at MMP-1 -1607, the mice with the $2 \mathrm{G}$ allele had higher levels of MMP-1 in their serum than those with $1 \mathrm{G}$ (36). Thus, it is reasonable to further examine the effect of the polymorphic site $M M P-1$ 1607 and other promoter polymorphic sites in the regulation 
of MMP-1 and tumor behaviors, such as brain and/or osteolytic metastasis.

In conclusion, our results suggest that the typical $1 \mathrm{G} / 2 \mathrm{G}$ $M M P-1$ polymorphic site did not play a direct determinant role in breast cancer among Taiwanese women. Further phenotypic studies such as the determination of MMP-1 levels in the serum of breast cancer patients and genotypephenotype correlation are warranted before the contribution of $M M P-1$ to breast cancer can be fully revealed.

\section{Conflicts of Interest}

The Authors declare no conflict of interest in regard to this study.

\section{Acknowledgements}

The Authors are grateful to Huai-Mei Hsu, Hsin-Ting Li and ShiouTing Yen for their excellent technical assistance. The clinical team of Dr. Su, Wang and Liu in sample collection and all the participants in this study are appreciated. This study was supported partially by a research grant from Taiwan Ministry of Health and Welfare Clinical Trial and Research Center of Excellence (MOHW107TDU-B-212-123004) and Taichung Armed Forces General Hospital (106A03) to Dr. Lai. The funders had no role in study design, data collection and analysis, decision to publish or preparation of the article.

\section{References}

1 Siegel RL, Miller KD and Jemal A: Cancer Statistics, 2017. CA Cancer J Clin 67: 7-30, 2017.

2 Chien LH, Tseng TJ, Chen CH, Jiang HF, Tsai FY, Liu TW, Hsiung CA and Chang IS: Comparison of annual percentage change in breast cancer incidence rate between Taiwan and the United States-A smoothed Lexis diagram approach. Cancer Med 6: 1762-1775, 2017.

3 Tsai HY, Kuo RN and Chung KP: Quality of life of breast cancer survivors following breast-conserving therapy versus mastectomy: a multicenter study in Taiwan. Jpn J Clin Oncol 47: 909-918, 2017.

4 Chambers AF and Matrisian LM: Changing views of the role of matrix metalloproteinases in metastasis. J Natl Cancer Inst 89: 1260-1270, 1997.

5 Sternlicht MD and Werb Z: How matrix metalloproteinases regulate cell behavior. Annu Rev Cell Dev Biol 17: 463-516, 2001.

6 Tsai CW, Chang WS, Gong CL, Shih LC, Chen LY, Lin EY, Li $\mathrm{HT}$, Yen ST, Wu CN and Bau DT: Contribution of matrix metallopeptidase-1 genotypes, smoking, alcohol drinking and areca chewing to nasopharyngeal carcinoma susceptibility. Anticancer Res 36: 3335-3340, 2016.

7 Sun KT, Tsai CW, Chang WS, Shih LC, Chen LY, Tsai MH, Ji HX, Hsiao CL, Liu YC, Li CY and Bau DT: The Contribution of Matrix Metalloproteinase-1 genotype to oral cancer susceptibility in Taiwan. In Vivo 30: 439-444, 2016.

8 Ye S: Polymorphism in matrix metalloproteinase gene promoters: implication in regulation of gene expression and susceptibility of various diseases. Matrix Biol 19: 623-629, 2000.
9 Price SJ, Greaves DR and Watkins H: Identification of novel, functional genetic variants in the human matrix metalloproteinase2 gene: role of $\mathrm{Sp} 1$ in allele-specific transcriptional regulation. J Biol Chem 276: 7549-7558, 2001.

10 Yu C, Zhou Y, Miao X, Xiong P, Tan W and Lin D: Functional haplotypes in the promoter of matrix metalloproteinase- 2 predict risk of the occurrence and metastasis of esophageal cancer. Cancer Res 64: 7622-7628, 2004.

11 Elander N, Soderkvist P and Fransen K: Matrix metalloproteinase (MMP) -1, -2, -3 and -9 promoter polymorphisms in colorectal cancer. Anticancer Res 26: 791-795, 2006.

12 Li Y, Jin X, Kang S, Wang Y, Du H, Zhang J, Guo W, Wang N and Fang S: Polymorphisms in the promoter regions of the matrix metalloproteinases-1, $-3,-7$, and -9 and the risk of epithelial ovarian cancer in China. Gynecol Oncol 101: 92-96, 2006.

13 Hu Z, Huo X, Lu D, Qian J, Zhou J, Chen Y, Xu L, Ma H, Zhu J, Wei Q and Shen H: Functional polymorphisms of matrix metalloproteinase- 9 are associated with risk of occurrence and metastasis of lung cancer. Clin Cancer Res 11: 5433-5439, 2005.

14 Chou AK, Hsiao CL, Shih TC, Wang HC, Tsai CW, Chang WS, Liu LC, Way TD, Chung JG and Bau DT: The Contribution of Matrix Metalloproteinase-7 promoter genotypes in breast cancer in Taiwan. Anticancer Res 37: 4973-4977, 2017.

15 Hung YW, Tsai CW, Wu CN, Shih LC, Chen YY, Liu YF, Hung HS, Shen MY, Chang WS and Bau DT: The Contribution of Matrix Metalloproteinase-8 promoter polymorphism to oral cancer susceptibility. In Vivo 31: 585-590, 2017.

16 Liao CH, Chang WS, Hu PS, Wu HC, Hsu SW, Liu YF, Liu SP, Hung HS, Bau DT and Tsai CW: The contribution of MMP-7 promoter polymorphisms in renal cell carcinoma. In Vivo 31: 631-635, 2017.

17 Shen TC, Hsia TC, Chao CY, Chen WC, Chen CY, Chen WC, Lin YT, Hsiao CL, Chang WS, Tsai CW and Bau DT: The contribution of MMP-8 promoter polymorphisms in lung cancer. Anticancer Res 37: 3563-3567, 2017.

18 Hu PS, Chang WS, Chou AK, Hsia NY, Hung YW, Lin CW, Wu $\mathrm{CW}$, Huang CY, Wu MF, Liao CH, Tsai CW, Bau DT and Gong CL: The association of MMP- 8 genotypes with Pterygium. In Vivo 32: 41-46, 2018.

19 Pei JS, Chang WS, Hsu PC, Hung YW, Cheng SP, Tsai CW, Bau DT and Gong CL: The contribution of MMP-8 promoter genotypes to childhood leukemia. In Vivo 31: 1059-1064, 2017.

20 Przybylowska K, Kluczna A, Zadrozny M, Krawczyk T, Kulig A, Rykala J, Kolacinska A, Morawiec Z, Drzewoski J and Blasiak J: Polymorphisms of the promoter regions of matrix metalloproteinases genes MMP-1 and MMP-9 in breast cancer. Breast Cancer Res Treat 95: 65-72, 2006.

21 Chou AK, Shen MY, Chen FY, Hsiao CL, Shih LC, Chang WS, Tsai CW, Ying TH, Wu MH, Huang CY and Bau DT: The association of Flap endonuclease 1 genotypes with the susceptibility of endometriosis. Cancer Genomics Proteomics 14: 455-460, 2017.

22 Lai YL, Gong CL, Fu CK, Yueh TC, Tsai CW, Chang WS, Hsiao CL, Yen ST, Li HT, Jeng LB, Wang SC and Bau DT: The contribution of matrix metalloproteinase-1 genotypes to hepatocellular carcinoma susceptibility in Taiwan. Cancer Genomics Proteomics 14: 119-125, 2017.

23 Egeblad M and Werb Z: New functions for the matrix metalloproteinases in cancer progression. Nat Rev Cancer 2: 161-174, 2002. 
24 Deryugina EI and Quigley JP: Matrix metalloproteinases and tumor metastasis. Cancer Metastasis Rev 25: 9-34, 2006.

25 Forget MA, Desrosiers RR and Beliveau R: Physiological roles of matrix metalloproteinases: implications for tumor growth and metastasis. Can J Physiol Pharmacol 77: 465-480, 1999.

26 Nikkola J, Vihinen P, Vuoristo MS, Kellokumpu-Lehtinen P, Kahari VM and Pyrhonen S: High serum levels of matrix metalloproteinase-9 and matrix metalloproteinase- 1 are associated with rapid progression in patients with metastatic melanoma. Clin Cancer Res 11: 5158-5166, 2005.

27 Yasui W, Oue N, Aung PP, Matsumura S, Shutoh M and Nakayama H: Molecular-pathological prognostic factors of gastric cancer: a review. Gastric Cancer 8: 86-94, 2005.

28 Curran S, Dundas SR, Buxton J, Leeman MF, Ramsay R and Murray GI: Matrix metalloproteinase/tissue inhibitors of matrix metalloproteinase phenotype identifies poor prognosis colorectal cancers. Clin Cancer Res 10: 8229-8234, 2004.

29 Bostrom P, Soderstrom M, Vahlberg T, Soderstrom KO, Roberts PJ, Carpen O and Hirsimaki P: MMP-1 expression has an independent prognostic value in breast cancer. BMC Cancer 11 : 348, 2011.

30 Wang C, Hu F, Guo S, Mi D, Shen W, Zhang J, Qiao Y, Zhu T and Yang S: BMP-6 inhibits MMP-9 expression by regulating heme oxygenase-1 in MCF-7 breast cancer cells. J Cancer Res Clin Oncol 137: 985-995, 2011.

31 Bachmeier BE, Nerlich AG, Lichtinghagen R and Sommerhoff CP: Matrix metalloproteinases (MMPs) in breast cancer cell lines of different tumorigenicity. Anticancer Res 21: 3821-3828, 2001.
32 Benaud C, Dickson RB and Thompson EW: Roles of the matrix metalloproteinases in mammary gland development and cancer. Breast Cancer Res Treat 50: 97-116, 1998.

33 Biondi ML, Turri O, Leviti S, Seminati R, Cecchini F, Bernini M, Ghilardi G and Guagnellini E: MMP1 and MMP3 polymorphisms in promoter regions and cancer. Clin Chem 46: 2023-2024, 2000.

34 Ghilardi G, Biondi ML, Caputo M, Leviti S, DeMonti M, Guagnellini E and Scorza R: A single nucleotide polymorphism in the matrix metalloproteinase-3 promoter enhances breast cancer susceptibility. Clin Cancer Res 8: 3820-3823, 2002.

35 Liu H, Kato Y, Erzinger SA, Kiriakova GM, Qian Y, Palmieri D, Steeg PS and Price JE: The role of MMP-1 in breast cancer growth and metastasis to the brain in a xenograft model. BMC Cancer 12: 583, 2012.

36 Tower GB, Coon CI and Brinckerhoff CE: The 2G single nucleotide polymorphism (SNP) in the MMP-1 promoter contributes to high levels of MMP-1 transcription in MCF-7/ADR breast cancer cells. Breast Cancer Res Treat 82: 75-82, 2003.

Received February 4, 2018

Revised March 11, 2018

Accepted March 12, 2018 